\section{Anthropocene and "Development": Intertwined Trajectories Since the Beginning of The Great Acceleration}

\author{
Antropoceno e "Desenvolvimento": Trajetórias Entrelaçadas Desde o \\ Começo da Grande Aceleração
}

\author{
Marina Dantas de Figueiredo ${ }^{10}$ \\ Fábio Freitas Schilling Marquesan ${ }^{1}{ }^{\circledR}$ \\ José Miguel Imas ${ }^{\circledR}$
}

\section{ABSTRACT}

Objectives: We aim to propose the thesis that the trajectories of the Anthropocene and the current mainstream understandings of development are intertwined from the beginning. It means that the Anthropocene and the "development" are coetaneous: the implementation of development policies for the so-considered underdeveloped regions started to happen at the same time of what is known as The Great Acceleration of production, consumption and environmental degradation in a global level. Method: In this conceptual paper, we adopt a decolonial critique as an analytical lens and argue that different geopolitical positions may be necessary for approaching the issue of the Anthropocene from epistemological reflections that can include the cultural and political context of the production and reproduction of local knowledge. Results: Our theoretical argumentation sheds light on the role of Global North and South relations in shaping the environmental crisis. Latin America (LA) exemplifies the modus operandi of the intertwinement of the practical effects of development policies and the environmental consequences underlying the Anthropocene, in which natural resources are over-explored to satisfy export-oriented trade, from the South toward the North. LA is not only a propitious context to show the validity of our thesis, but also the source of alternatives to such developmental model. Conclusion: The emphasis on development as a cause of the Anthropocene supports The Great Acceleration thesis. The proposition of the name Developmentocene comes from the thesis that development and Anthropocene are coetaneous, the intertwinement of both resulting in the very definition of the new epoch.

Keywords: anthropocene; development; the great acceleration; organization studies; latin america.

JEL Code: O1, F54, Z13.
${ }^{1}$ Universidade de Fortaleza, Programa de Pós-graduação em Administração, Fortaleza, $\mathrm{CE}$, Brazil.

${ }^{2}$ Kingston University, Thames, United Kingdom.

Cite as: Figueiredo, M. D. de, Marquesan, F. F. S., \& Imas, J. M. (2020). Anthropocene and "development": Intertwined trajectories since the beginning of the great acceleration. Revista de Administração Contemporânea, 24(5), 400-413. https://doi.org/10.1590/1982-7849rac2020190400

\section{RESUMO}

Objetivo: Buscamos propor a tese de que as trajetórias do Antropoceno e o entendimento atualmente dominante sobre desenvolvimento estão entrelaçadas desde o começo. Isso implica que o Antropoceno e o "desenvolvimento" são coetâneos: a implementação de políticas de desenvolvimento em regiões tidas como subdesenvolvidas começou a acontecer ao mesmo tempo em que teve início A Grande Aceleração da produção, do consumo e da degradação ambiental em nível global. Método: Neste artigo conceitual, nós adotamos a crítica decolonial como lente analítica e argumentamos a necessidade de diferentes posições geopolíticas para abordar a questão do Antropoceno a partir de reflexões epistemológicas que possam incluir o contexto cultural e político de produção e reprodução do conhecimento. Resultados: Nossa argumentação teórica enaltece as relações entre o Norte e o Sul Global no delineamento da crise ambiental. A América Latina (AL) exemplifica o modus operandi do entrelaçamento entre os efeitos práticos das políticas de desenvolvimento e as consequências ambientais subjacentes ao Antropoceno, em que os recursos naturais são explorados além dos limites para satisfazer o comércio para exportações, desde o Sul para o Norte. Nesse quadro, a AL não é apenas um contexto propício para mostrar a validade da nossa tese, mas também a fonte de alternativas a esse modelo de desenvolvimento. Conclusão: A ênfase no desenvolvimento como causa do Antropoceno apoia a tese da Grande Aceleração. A proposição do nome Desenvolvimentoceno advém da tese de que o desenvolvimento e o Antropoceno são coetâneos e que o entrelaçamento de ambos resulta na própria definição da nova época.

Palavras-chave: antropoceno; desenvolvimento; a grande aceleração; estudos organizacionais; américa latina.

\# of invited reviewers until the decision

\begin{tabular}{|c|c|c|c|c|c|c|c|c|c|}
\hline & 1 & 2 & 3 & 4 & 5 & 6 & 7 & 8 & 9 \\
\hline $1^{\text {st }}$ round & $\stackrel{0}{2}$ & $x$ & $x$ & $x$ & $x$ & $x$ & 2 & x & \\
\hline $2^{\text {nd }}$ round & 2 & 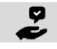 & & & & & & & \\
\hline $3^{\text {rd }}$ round & 0 & & & & & & & & \\
\hline
\end{tabular}

Editor-in-chief: Wesley Mendes-Da-Silva (Fundação Getulio Vargas, EAESP, Brazil) Reviewers: Cintia Medeiros (Universidade Federal de Uberlândia, FAGEN, Brazil) (t) André Ferreira (Universidade Federal Fluminense, PPGAd, Brazil) (c) 


\section{INTRODUCTION}

The concept of the Anthropocene has become increasingly influential since its proposition twenty years ago (Crutzen \& Stoermer, 2000). It may be considered a new epoch in natural history, derived from human action, notably the action of the "civilized man" (Steffen, Grinevald, Crutzen, \& McNeill, 2011, p. 843) that have become pervasive and profound enough to rival the great forces of nature in reshaping the planet's surface (Steffen, Crutzen, \& McNeill, 2007). Initially, epistemological perspectives apparently free of ideologies from the Natural Sciences have assumed the mainstream position in the theoretical elaborations over it, but the Social Sciences further engaged with the concept, channeling its critical potential to the content and politics of scientific inquiry (Lorimer, 2017).

The Anthropocene stresses the human action in shaping nature, which requires analytical strategies that can include narratives of human history within the broader framing of Earth history. However, questions regarding how they entwine, and from what precise milestone, reveals the controversies of aggregating elements of historical and socioeconomic analysis with geophysics (Steffen, Broadgate, Deutsch, Gaffney, \& Ludwig, 2015). The Anthropocene idea offers an occasion for passing judgment on humanity's domination of nature (Ellis \& Trachtenberg, 2013), and it engenders the possibility of questioning the values and premises of Western philosophy and politics (Lewis \& Maslin, 2015). Underlying the many different propositions toward the Anthropocene's definition, there are diverse standpoints about how to define humanity, and what forces and interests are at stake in human action over nature.

Among these many different propositions, the Great Acceleration thesis reveals the detrimental effects of the economic activities of the Northern developed countries in the Earth-System. It refers to the period "around 1945 when the most rapid and pervasive shift in the human-environment relationship began" (Steffen et al., 2007). The Great Acceleration refers to the interconnectedness of cultures, accelerated by developments in electronic communication, fast-moving of goods, the drop in the cost of international travel, and the globalization of economies that have aided shaping contemporary consumerist lifestyles, particularly in the Global North. The thesis acknowledges that the Global South was by no means callous to these transformations, and took part on the full integration of a global matrix of production, distribution, and consumption of goods, services, circulation of people and processes on a world scale. However, it falls short in describing such a process and relating it to an encompassing political event of that same time, namely the conception and leaps toward practice of the idea of (under)development.

In this regard, we understand that the dynamics of economic activities between the Global South and North are inseparable (Böhm \& Misoczky, 2010), and we plea the interpolation of both featuring the Anthropocene. For that reason, we ask in this paper how do the Great Acceleration relates to the politics of development carried out to the underdeveloped world. From that landmark of the Anthropocene, we understand that environmental degradation dovetails the development agendas espoused by or imposed on the Global South. Therefore, in this conceptual paper we aim to propose the thesis that the trajectories of the Great Acceleration and the development are intertwined from the beginning. That is to say that the Anthropocene and the current mainstream understandings of development are coetaneous.

By adopting a decolonial critique as an analytical lens, we argue that different geopolitical positions may be necessary for approaching the issue of the Anthropocene from epistemological reflections that can include the cultural and political context of the production and reproduction of local knowledge. It may enable conciliatory practices of socio-economic change between the Global North and South, the interests of both parties, and the needs of the human species about the rights of nature. Nevertheless, the human species is not an integrated whole, and the rhetoric of the species hides "the vast diversity of people, cultures, ideologies, agencies, and histories" (Lepori, 2015, p. 109) that make up human societies. Aware of that, we understand the importance of broadening the debate on the Anthropocene in LA, and we restate the need to resume the current discussion on the Anthropocene in the Social Sciences, particularly in the field of Organization Studies (OS).

The issues surrounding the Anthropocene are still little explored by researchers based in the Global South, as pointed out by García-Acosta (2017). The region is home to some of the largest biodiversity reserves on the planet, like the Amazon rainforest. Despite this environment's wealth (or, precisely, because of it), Latin America (LA) is historically the stage of violent spoliation (Galeano, 2010; 
Ulloa, 2017). Since the 16th century, the region has consistently contributed to the consolidation of a global circuit of raw material extraction as a supplier of primary commodities of low added value to the world (Chagas, Carvalho, \& Marquesan, 2015). Until nowadays, the development model adopted in most countries of the subcontinent has export-oriented extraction as the main driver of economic activity. The mining and export agribusiness frontiers advance on conserved natural areas and over the rights of communities living in those places in the name of the development of the region.

There is a broad understanding that the Anthropocene's effects on both nature and society require transdisciplinary knowledge and efforts, and the participation of social scientists engaged in delineating possible ways of dealing with the impact of human activity on the planet (Lepori, 2015; Lövbrand et al., 2015). However, within the field of OS, there is still little active commitment to "take responsibility for living in the Anthropocene" (DeCock, Nyberg, \& Wright, 2019). Reflections on development and contributions on the issue of the Anthropocene fall within OS because organizations are the means for economic and political projects to materialize in practice. Bounded to this field is to elaborate the transition from theory to practice of conducting business in areas exposed to climate change or deeply affected by the loss of biodiversity, for example. OS offer the possibility of understanding that new types of organizations and what alternative forms of management are needed to meet the challenge of transforming production and consumption to conserve and restore nature.

In the following sections, we recover the scientific trajectory of the Anthropocene, both in Natural and Social Sciences to further assume The Great Acceleration as the landmark of the new geological epoch, and to highlight the implications of colonial and neo-colonial relations in featuring the Anthropocene. Then, we reflect upon the impact of organized human action on the planet within the mainstream political framings of development. Moreover, we trace the development trajectory of LA, from the aftermath of World War II to the neodevelopmental models of the 2000s, to elaborate on how the dynamics of extraction, transformation, and circulation of natural resources had pushed the limits of the planetary threshold from the second half of the 20th Century on. Beyond what has been stated to support the thesis proposed in this paper, we also turn our attention to alternative development models, in an overview that recovers some original pieces of LA thought. Finally, we elaborate on the potential of the Anthropocene concept, as a new scientific fact, to prompt a scientific project that could recover LA original thought in the search for new perspectives about development and the broader idea of good living.

\section{UNDERSTANDING THE ANTHROPOCENE FROM DIFFERENT POSSIBLE DATES FOR THE START OF THE NEW EPOCH}

Although there is no consensus on the transition from geological times by scientific communities of Natural Sciences, there is growing evidence that humans act upon the planet has changed in recent times, and such a movement destabilizes the climatic conditions of the previous epoch, the Holocene. In the past, human activities were not intense enough to leave clear stratigraphic records, but today the magnitude of transformations on short time scales had left uncontested marks on sedimentary rocks, glacial layers, soils, and woods, indicating new paths on the dynamics of the Earth.

So far, several possible start dates for the new epoch have been into consideration, reflecting different perspectives and disciplinary criteria. Researchers have tried to establish landmarks, mainly through stratigraphy, that is, in the search for global and accentuated signs of human action recorded in rocks. However, different perspectives on how human affairs impact nature are in dispute, and we shall briefly discuss three main landmarks, among many others, put forward in the scientific arena. By mentioning possibilities and eventually framing our thesis in relation to a landmark, we do not aim to rule the concept of Anthropocene but to discuss its failure to accept a diversity of origins to the phenomena (González-Ruibal, 2018). These landmarks are the Industrial Revolution, the Orbis Spike, and the Great Acceleration thesis.

The Industrial Revolution was initially singled out as the Anthropocene trigger (Crutzen \& Stoermer, 2000; Steffen et al., 2011) because the boost of fossil fuel use along with the rapid societal changes has announced significant and unique transformations in the Earth's natural history. However, the lack of stratigraphic evidence has made this landmark questionable for some scientists (Certini \& Scalanghe, 2011; Lewis \& Maslin, 2015). The arguments against such a milestone state that: (a) the Industrial Revolution was an asynchronous and localized event in Northern Europe (Lewis \& 
Maslin, 2015); and (b) at that time, many parts of the Earth's surface had already been profoundly modified by pre-industrial human activities (Kirsch, 2005). Even so, the Industrial Revolution caused a significant increase in the burning of fossil fuels, shown by the composition of air trapped in polar ice layers and ice caps, corresponding to a rise in carbon dioxide and concentrations of methane in the atmosphere.

Another proposed landmark, the so-called Orbis Spike, points to the year 1610 and the impact of the early colonial process in the Americas on the shaping of the face of Earth in the Anthropocene (Lewis \& Maslin, 2015). The Orbis Spike is a stratigraphic record of the decrease of atmospheric carbon dioxide (CO2) due to the decline in agricultural activities in America and the regeneration of a large area of the continent's forests after the arrival of Europeans and the mass-deaths of aboriginal population (which estimated number vary from 6 million people (Dull, Nevle, Woods, Bird, Avnery, \& Denevan, 2010) to 50 million people (Biello, 2015) between 1492 and 1650 .

Alternatively, the Great Acceleration thesis highlights the intensification of human activities on Earth from the mid-20th Century. It is based on a compendium of evidence from a longitudinal analysis of both natural and social trends from 1795 to 2000. Steffen, Crutzen, and McNeill (2007) state that the Anthropocene unfolds in two stages, the first between 1800-1945 and the second starting from 1945. In the early stage, industrialization played a central role in expanding the use of fossil fuels, first coal and then oil and gas. Around 1945 the humanenvironment relationship changed drastically because "out of World War II came a number of new technologies - many of which represented new applications for fossil fuels - and a commitment to subsidized research and development, often in the form of alliances among government, industry, and universities" (Steffen, Crutzen \& McNeill, 2007, p. 618). Albeit the Great Acceleration thesis has no specific stratigraphic record, it could be related to the so-called bomb spike of 1964, which is the mark of radioactive presence on ice layers formed in the 1960s when tests involving nuclear explosions reached the apex (Waters et al., 2016).

Steffen, Broadgate, Deutsch, Gaffney and Ludwig (2015) further concluded that "only beyond the mid-20th Century is there clear evidence for fundamental shifts in the state and functioning of the Earth System that are beyond the range of variability of the Holocene and driven by human activities" (p. 81). The historical comparison of socio-economic trends shows the activity of the wealthy (OECD) countries, emerging economy countries, and the rest of the world changed effectively in the analysis of the 2000-2010 period. Steffen et al. (2015) also deliver arguments to link the Great Acceleration to a change in the dynamics of the relations between global North and South. For instance, most of the population growth has been in the non-OECD world. However, the world's economy (GDP) is still strongly dominated by the OECD world (in 2010, the OECD countries accounted for $74 \%$ of global GDP but only $18 \%$ of the global population). Another remarkable observation is the shift of global production, traditionally based within OECD countries, towards the BRICS nations (especially China), even though the bulk of economic activity and the most significant share of consumption remain mostly within the OECD countries.

As the search for landmarks express, human, and natural history interact in the concept of the Anthropocene. Some Earth scientists underscore the need to deepen the search for stratigraphic evidence to define the new epoch (Lewis \& Maslin, 2015), albeit the human permeation of global processes also stresses that their subject matter demands a kind of moral engagement (Ellis \& Trachtenberg, 2013). Some others say that the search for landmarks should not rely on stratigraphy alone. For instance, events like the Industrial Revolution did not produce accurate stratigraphic records, but they impacted the human relationship with the environment in unquestionable ways (Hamilton, 2015). The strife is not only about fixing a landmark, but also uncovering the forces driving the human acting upon nature, whether the fossil-fuel-based industrial processes (Crutzen \& Stoermer, 2000), or colonization, and colonial relations (Lewis \& Maslin, 2015) or contemporary patterns of consuming-living (Steffen et al., 2015). There is also the possibility of the interaction between the propositions, as the complex shaping of the planet Earth may not be assigned to a single event. For the thesis we present in this paper, defining the Anthropocene is not only about choosing landmark criteria but unveiling the complex of relations that are shaping it from the beginning. 
HUMAN ORGANIZED ACTIVITY AND THE ANTHROPOCENE: THE SEARCH FOR ALTERNATIVE NAMING OF THE NEW EPOCH

The Anthropocene definition, origin, and classification are controversial, and so is the issue of how the new epoch should be called, particularly outside of the Natural Sciences. The conceptual dissent over the stratigraphic evidence of human action on Earth tends to unfold or bolster ideological and theoretical-epistemological debates, in the most different fields of Social Science studies. For Ellis and Trachtenberg (2013), the Anthropocene goes beyond geology to public discourse. They mention the 'excitement', meaning 'a buzz' brought up by the word in the scientific arena of different fields and also in the media because it evocates the notion that humanity has attained the status of a force of nature. If the human activities recognizable for producing the Anthropocene are the result of choices, the exploration of the relationship between values and action in Philosophy, Psychology, Law, and so on requires the input of Social Sciences.

The discourses on the Anthropocene (Lepori, 2015) demonstrates the importance of scrutinizing the existence of power relations, struggles, and differences of interests and benefits concealed under the thought and practice of some environmental policies. Alternative naming for the new epoch also disheartens the shortcomings of adopting a geological framework that blames all humans and all organizational activities equally for a specific effect of modernity, colonial relations, and capitalism (González-Ruibal, 2018). Terms such as Capitalocene (Moore, 2016), Plantationocene (Haraway, 2016), and Anglocene (Baviskar, McFarlane, Mawdsley, \& Jazeel, 2015; Svampa, 2016), among others, have been used to define the Anthropocene, from the standpoint of politicaleconomic perspectives. Stratigraphic frameworks are not necessarily underlying these alternative naming propositions. Still, they can contribute to landmark thesis, as well as to provide a critique of the use of the Anthropocene by revealing that the new geological epoch may have particular political, economic, cultural, and geographical causes.

Malm and Hornborg (2014) argue that the distribution of those responsible for climate change and other changes in the geomorphology of the planet are concentrated among the wealthiest, while the disadvantaged suffer it more drastically. Against Anthropocene's shallow historicization, the concept of Capitalocene (Moore, 2016; 2017) would be more appropriate to define the new epoch and better express the fact that the responsibility on the transformations that the planet is going through is bounded within a system of power, profit and (re) production in the web of life. The Capitalocene criticizes how the Anthropocene introjected the narrative of modernity as the separation of man from nature and points out the origins of the modern world to be found in Britain, in the down of the 18th Century. It goes along the thesis of the Industrial Revolution as a landmark for the Anthropocene, understanding it as "as a set of technical, class, and sometimes political relations emerging around coal and steam between 1760 and 1830" (Moore, 2017, p. 2). Hitherto the relation of humanity and nature changed radically so that the history of capitalist origins is also the origins of ecological crisis.

The Capitalocene aims to reveal the uneasy relationship to the Human/Nature binary, and its reluctance to consider human organizations - like capitalism - part of nature (Moore, 2017). There are open possibilities for researchers in the Social Sciences and particularly in OS, to problematize these perspectives and to search alternative ways for understanding the Anthropocene and its socio-environmental consequences on a global scale, particularly concerning the role of different modalities of organized human activities and its impacts over nature. Human activity causing the Anthropocene demands a better understanding of the organizational forms of the various societies involved in this state of affairs.

The Capitalocene speaks about a way of organizing nature under the rules of reproduction of capitalism, taken as a historical process. It addresses colonial relations of the appropriation of nature as a cheap resource in the process of commodification of land, water, forests, crops, and animals - humans included - encompassing exploitation techniques to make nature work for free. The emphasis on such colonial relations is further elaborated under other alternative names for the new epoch. According to Haraway (2016), the issues about naming Anthropocene, Capitalocene, Plantationocene - and we add Anglocene - "have to do with scale, rate/speed, synchronicity, and complexity" (p. 99) of human-induced changes over nature. The name Plantationocene defines "the devastating transformation of diverse kinds of human-tended farms, pastures, and forests into extractive and enclosed plantations, relying on slave labor and other forms of exploited, alienated 
and usually spatially transported labor" (Haraway, 2016 , p. 206). The Plantation system of agricultural production was capital to the colonization of the Americas, and the basis for its implementation relies on the profound transformation of the environment in one sole monocultural ground, destroying the cultural and biological diversity. Haraway, citing Tsing (2015) "suggest that the inflection between the Holocene and the Anthropocene might be the wiping out of most the refugia from which diverse species assemblage (with or without people) can be reconstituted after major events (like desertification or clear cutting)" (Haraway, 2016, p. 100). The Plantation is not only a system of agricultural production but a way of organizing nature toward productive aims to make it cheaper. The critique placed by the Plantationocene relates to such an idea, highlighting the monocultural assumptions of the Anthropocene.

Still regarding alternative naming, it is also arguable to what extent the Anthropocene universalizes agencies that are restricted to cultures and even nation-centered histories. The concept of the Anglocene expresses how the proposition of the Industrial Revolution as a landmark relates the new epoch to a northern European and mainly British historical event. The Anglocene frames the Anthropocene not only in terms of a new temporal scale but also a geographical perspective of power and knowledge production of its causes and consequences. As the original proposition of the Anthropocene universalizes local acting, the idea underlying the Anglocene localizes these very acting. It allows us to think about which actors are legitimized and which are excluded. Although closely related to decolonial critique, the idea of Anglocene highlights imperial relations of power that entangles spatial divisions of labor, displacing production to locations with more or less appropriate land and/or labor, in management of ecosystems. As Morrison $(2018$,) comments, "the classic examples of such displacement are plantations run by temperatezone polities producing labor-intensive tropical commodities such as sugar, tea, rubber, coffee, and indigo", and "extractive work such as mining would also fit here" (p. 200). The Anglocene relates imperial practices to the human-environment relation, shaping it with difference, distance and displacement.

Besides the three concepts that we have presented here, the Anthropocene can raise many other alternative viewpoints (for example, see Haraway, 2016). Despite the critical potential of each, and they combined, the many possible approaches to how the planet is changing in the Anthropocene shall affect how we understand organizations in the capitalism and the hierarchical status of human action in organizing the world. For the sake of this paper's thesis, the previous discussion on stratigraphy and landmark search may converge with the search for naming the new epoch, either within the Anthropocene's framing or in its critiques. The issue of naming is still more point-blank in reveling the agents and agencies in organized schemes responsible for anthropogenic changes upon nature.

As an overview of the two previous sections, it is worth condensing what was said: the first thesis that proposed a landmark for the beginning of the Anthropocene indicated the Industrial Revolution of 1750. That is in line with the most recognized alternative naming to date: the Capitalocene, which bases go back, precisely, to the time of the Industrial Revolution. Then, the Orbis Spike comes as an alternative thesis, emphasizing the invasion of the Americas by the Europeans from 1492. Such a landmark aligns with the Plantationocene - the practice of plantations being widely applied in the exploration of the new world (hitherto endurings). Finally, we link up with the proponents of The Great Acceleration thesis as a landmark of the beginning of the Anthropocene, dating back to the middle of the 20th century. But an alternative naming for the new epoch, such as Capitalocene or Plantationocene (or even Anglocene), would be lacking. What we argue here is that the pro-development policies and actions led initially by the United States, mainly triggered after the end of World War II, could answer the question. Would we be living, then, in the epoch of Developmentocene?

\section{DEVELOPMENT, UNDERDEVELOPMENT, AND LATIN AMERICA: HOW AND WHY IS DEVELOPMENT COETANEOUS OF THE ANTHROPOCENE?}

It seems there is still lacking theorization on the relationship between the trajectory of the Anthropocene (Crutzen \& Stoermer, 2000) and that of what is considered as development since the Great Acceleration of industrial activities and consumption that spread throughout the world shortly after the end of World War II (Steffen et al., 2007). We seek to highlight that the updated version of the Great Acceleration thesis reveals that the economic activity of the human enterprise continues 
to grow at a rapid rate. Still, one shall distinguish the human activity causing the Anthropocene from one single, monolithic whole. That "ignores the fact that the Great Acceleration has, until very recently, been almost entirely driven by a small fraction of the human population, those in developed countries" (Steffen et al., 2015, p. 91). Once development relies on the perpetual recognition and disavowal of difference, inherent to discrimination, the artificial construct of underdevelopment is discursively built by the signifiers "poverty", "illiteracy", "hunger" (Escobar, 1997, p. 93). Those refer to the condition of LA, where human's poverty is a consequence of the wealth of the land (Galeano, 2010). From this part of the world, but also all the Global South, one must understand development as a historical process, "which started some two centuries ago and continuously transforms our world" (Rist, 2019, p. 488).

The development has been subject matter for a long time now, and a buzzword in trend for 70 years (Rist, 2019). Never before a political concept has been so elusive, resting on a mere - albeit unquestioned - assumption which no one dared or cared to define accurately (Rist, 2019). And "never before had a word been universally accepted on the very day of its political coinage" (Esteva, 2010, p. 2). That day is precisely 20 January 1949 , when US-president Harry S. Truman "merely wanted to include in his 1949 Inaugural Address a fourth point that would sound 'a bit original'" (Rist, 2019, p. 485). Strangely enough, the chosen word to coronate the speech was 'underdevelopment', so the international career of the word development started as a presumption. It carried an antagonism - colonizers vs. colonized - twisted into a new perspective, of "equal members of the same family, henceforth considered more or less 'developed'" (Rist, 2019, p. 486). The ones all over the world called underdeveloped, "in all their diversity, were transmogrified into an inverted mirror of other's reality ... simply in terms of a homogenizing and narrow minority" (Esteva, 2010, p. 2).

With an "unsuspected colonizing virulence" (Esteva, 2010, p. 2), the absence of a real definition for development and underdevelopment allowed the common sense appropriations of it with "a topdown, ethnocentric and technocratic approach" (Escobar, 1997, p. 91). The many targets of development after 1945 had in common some new articulation of elements of Modernity that conceived it as "a system of more or less universally applicable technical interventions" (Escobar, 1997, p. 91). Societies from the Global North - headed by the US - assumed their models of civilization as universal, and their global pacts for development could hold the implied promise of generalized happiness. That proved enormously useful and, in a milieu of renewed prosperity after World War II, ensured unprecedented funding for science and technology, unprecedented recruitment into these fields, and unprecedented advances as well (Steffen et al., 2015). While development fostered the way of conceiving social life as a technical problem to be solved by experts (particularly 'development economists'), "underdevelopment became the subject of political technologies that sought to erase it from the face of earth, but that ended up, instead, multiplying it to infinity" (Escobar, 1997, p. 91).

At the end of the 1960s, "it became clear that rapid growth had been accompanied by increasing inequalities" (Esteva, 2010, p. 10), which forced the economic definitions of development to merge to a more social-oriented perspective. As Esteva (2010) tells, the question was addressed in 1970 by the president of the World Bank. In the same year, there were some initiatives of the UN to recognize a unified approach to development, which would fully integrate the economic and social components of development analysis and planning. At the same pace, the Great Acceleration precipitated by development took place in an intellectual, cultural, political, and legal context in which the growing impacts upon the Earth System counted for very little in the calculations and decisions made in the world's ministries, boardrooms, and laboratories (Steffen et al., 2015). In the late 1960s and early 1970 s, environmental issues rose as dilemmas for development, also because they unveiled the development of poor regions of the world could bring environmental disorders that would be contrary to the project of overspread harmony via economic and social planning.

For instance, since about the 1970s, most of the increase in fertilizer consumption has occurred in BRICS nations. As the middle classes of those regions grow, the Great Acceleration can no longer be said to be driven by a small fraction of the human population, those in developed countries (Steffen et al., 2015). Following such an argument, Steffen et al. (2015) not deepen the reflection on how and why agricultural production from the BRICS serves the OECD consumption needs since imperial-colonial relations were not the central point of the Great Acceleration thesis. However, we point out that the increase in global South production integrates 
the development dynamic of such regions. Under the development logic, underdeveloped regions must find their path to development basing their economies in nature's extraction that serves as cheap raw materials to the industrial production that sustains the lifestyles of developed regions, defined as such by their very affluence.

Lane (2019), who recently has raised a discussion about the American Anthropocene and the Great Acceleration, considers "the framing of the Anthropocene as embedded in societies and their traditions while simultaneously focusing on the specific, qualitative changes underpinning the Great Acceleration from the 1950s onward" (p. 3). Lane (2019) reiterates that one should not understand the Anthropocene as a consequence of the acts of universal humanity outside of time. However, the oxymoronic phrasing of the American Anthropocene leaves aside the political implications of taking America as a synonym of the United States of America and the Americans as the citizens of that country. We acknowledge the global spread of the so-called American economic technologies and discourse played a central role in the Great Acceleration. However, we state that the adjective American leaves undone the task of adding plurality to the definition of the Anthropos in the Anthropocene and discussing it under the basis of power relations. It should be extended to the entire continent or be called by another name. If American Anthropocene refers to the action of the United States, so it is another facet of the Anglocene (Baviskar et al., 2015; Svampa, 2016). The idea of Lane (2019) falls short in addressing the dynamics of dependency within the American continent regarding the Great Acceleration.

Driven by the environmental crises that human activities in the capitalist system caused to the Earth-System, there was the need to integrate a third party - along with economic and social - to the conceptual framework of development. In the late 1980s, the Brundtland Commission prescribed the new idea of sustainable development, actively promoted as green and democratic. In the following decades, such a view has dominated the global political scenario and played a central role in the UN agenda -expressed, for instance, in the 2030 Agenda and the 17 Goals for Sustainable Development. However, the mainstream interpretation of sustainable development seems to "conceive it as a strategy for sustaining 'development,' not for supporting the flourishing and enduring of an infinitely diverse natural and social life" (Esteva, 2010, p. 13).

The belief in the development of societies and countries, supported by the economic perspective of growth, also becomes downplayed when we think that nothing and no one will be exempt from the significant challenges of the Anthropocene. These challenges are different in developed and underdeveloped countries, but the poor ones are likely the most vulnerable to socio-environmental disasters. The adjective 'Sustainable' going along with development is questionable because some lifestyles related to consumption patterns of rich countries have a direct impact on the degradation of nature, and the extension to the inhabitants of underdeveloped countries could cause environmental collapse. As Steffen et al. (2015) point out, "in a practical sense, the future trajectory of the Anthropocene may well be determined by what development pathways urbanization takes in the coming decades, particularly in Asia and Africa" (p. 91). It is suggestive that the development pathway followed by the rich countries, drivers of the Great Acceleration, do not necessarily have to be followed by other nations. But for that, we need to acknowledge alternatives to development.

Some alternatives to the dominant development model in contemporary society

Alternatives to development aim to break the boundaries of current development rationality and move towards radically different strategies, based on other ideological foundations regarding ways of understanding nature and society, institutions, and discursive defenses (Gudynas, 2013b). By suggesting alternatives, we are not arguing that existing propositions escape from the 'development' bias, nor that they are a complete theoretical corpus, nor they are feasible at this moment. But the Anthropocene urges alternatives that may come from the North or the South, and of both interacting. We shall mention four different propositions terms of epistemological assumptions, level of theorizing, and the public attention they have received to the date. Those are the ecodevelopment, the sustainable degrowth, the circular economy (and/or bio green economy), and the post-extractivism. Our aim here is not critically analyzing them, but just remarking their central core.

First, the ecodevelopment (Sachs, 1981) grandfathered sustainable development assembling environmental and economic views. It emerged 
from the 'development crisis' of the 1970s, that gained momentum for discussing the idea of reuniting environment and development, both in the Global South (particularly in LA), and in progressist intellectual groups from the Global North. In the bullet of the 'development crisis', other theoretical and political proposals also emerged to reconcile (or not) the issue of economic growth with the need to stop environmental destruction.

The second proposition, the de-growth perspective (Kallis, Kershner, \& Martinez-Alier, 2012), opposes the growth paradigm dominating practices and policies since World War II. It states for the "equitable decrease of production and consumption, which increases human well-being and improves local and global ecological conditions in the short and long term" (Schneider, Kallis, \& Martinez-Alier, 2010). It is both a social grassroots movement from the Global North and a concept that was captured in the academic circles of the Global South, initially in the South of Europe, and then to the collaborative efforts with LA thinkers.

The third perspective to be mentioned is the circular economy, which "is currently a popular concept promoted by the EU, by several national governments and by many businesses around the world" (Korhonen, Honkasalo, \& Seppälä, 2018, p. 37). It is not opposed to sustainable development, but elaborates a new version of it, shifting the linear model of production and consumption to a circular one, limiting growth to what is called the planetary boundaries. It is very dependable on ideas such as eco-efficiency and the increasing use of technologies (mainly social technologies) to promote product reuse, remanufacturing and refurbishment, to increase the use of resources and energy. The time and the value in the resources spends/lives within the inner circles should be maximized. So far, it seems that the circular economy perspective is becoming a pathway for Western Europe, but it might be questionable in other parts of the world that base their development models on the extraction of raw materials.

The fourth perspective states for the transition to post-extraction models of economy, given the persistence of the conventional model of development, despite the evidence of limitations and harmful effects. According to Gudynas (2013a), the shift away from predatory extraction will need to overcome various obstacles. In the face of the persistence of current development models, despite all the evidence of its constraints and detrimental impact, the thinking about transitions to postextraction in LA must both defend and promote the validity of alternatives to the development and explain the need for them.

The extraction of natural resources is the driving force behind a development model for LA that has accelerated cultural losses as far as aggravating the environmental crisis. Selling low price raw materials and buying expensive industrial products in the international market. Extraction involves mining on any scale, large scale agriculture to exportation, and exploitation of animals of any size in medium and large scale and oriented to the commercialization in distant places, mainly in export markets. That is supported by scientific and technological development, put into practice with technical packages geared by political interests and economic development. Such a model causes irreparable socio-environmental damages by imposing the cycle of the consumer market on nature and disrespecting the knowledge and cultural identities of the people affected by such activity.

In recent years, intensification in the extraction of raw materials - metals, minerals, hydrocarbons, and so on - along with the expansion of export-oriented agro-industrial modes have been proposed by national governments, regional development banks, and international organizations as an essential development strategy for the Global South. Since the 1990s, national governments in LA have once again sought to promote large-scale, export-oriented mining and agricultural activities in an attempt to foster a neo-extractive style of development (Gudynas, 2013b; Svampa, 2016). In this model, the intensification of extractive activities already developed in the subcontinent occurred through a promise of development in a context of changes in global economic policy, in which natural resources turn into low added-value raw materials, known as commodities, would gain prominence.

In pursuit of a conceptual framework on the appropriation of natural resources, Gudynas (2013b) sought to elaborate a "classification of natural resource extraction" (p. 2). The first step would be to recognize the existence of at least two modes of human interaction with the environment. In some cases, there is little impact on the environment because humans remove a few elements from nature. In other cases, the extraction of resources occurs through means that imply more massive impacts on the environment. For Gudynas (2013b), "under this situation is the extractivism" (p. 2) but to establish 
a classification that differentiates the types of extraction and extractivism, the author considers three fundamental dimensions: the volume of resources extracted, the intensity extraction and commercial use of resources. In this way, the amount and intensity of the extraction related to the commercial destination of the resources feature certain types of extraction of natural resources as extractivism.

We propose the theoretical elaboration of a critique of the development model adopted in LA based on the evidence of its impact on the Anthropocene pari passu the proposition of alternatives to it. Aligned to this commitment, in the next section, we seek a postcolonial methodological framework based on the Paradigm Other (Mignolo, 2000) to a scientific project on the Anthropocene in LA. It arises from the understanding that decolonization is not an object but an autochthonous force to "think of the intersection of the experiences that the knowledge of modernity relegated to the objects of colonialism, with decolonization as the critical force of the subject who does not want to 'study' (himself as an object, but rather to 'think' about himself in liberating and emancipatory projects" (Mignolo, 2000, p. 31).

\section{THE ANTHROPOCENE AS A SCIENTIFIC PROJECT FOR LATIN AMERICA}

The novelty of the Anthropocene in science as a whole makes researchers face methodological and practical problems, as the contention about the definition of the stratigraphic landmark, or the name of the new epoch can illustrate well. The engagement of the Social Sciences in the issue also reveals epistemological problems and uncertainties in the very scientific status of the Anthropocene and its criticism in the realm of modern science. Therefore, we understand that the theoretical critique of the development model adopted in LA from the Paradigm Other decolonial perspective serves the purposes of the engagement of the Social Sciences with the issue of the Anthropocene. Much because it rekindles the postmodern debate about the scientific character of the Human Sciences concerning the Natural Sciences. Such issues focus on the distinction between both forms of knowledge, elaborating a line of reasoning that - in the decolonial context of the work of Santos (2010) - gives rise to abyssal thinking. The abyssal thinking consists not only on the concession to the modern science of the monopoly over the universal distinction between true and false. Even though part of the Social Sciences follows the Modern Science presumptions, some streams of the Earth-System Sciences disagree that social scientists should take part in the construction of the Anthropocene concept (Castree, 2017). Such opinion is based mainly on technical and methodological issues of the so-called Hard Sciences, which exclude other possibilities of knowing.

From a decolonial perspective, the Paradigm Other bases the awareness of the transformations necessary to society in the face of the Anthropocene. The Paradigm Other central issue is the possibility of being shared by those who experienced, lived, and thus learned in their bodies the trauma that the disrespect and ignorance about human and nature rights causes over the majority of the inhabitants of the planet. Those people do not experience the benefits of the so-called well-being prompted by economic development and need to 'relearn to be' in the context of environmental degradation. The Paradigm Other is ultimately the name that connects critical forms of emerging South Global thinking (the Americas of Latinos, African Americans, Native Americans, Critical Thinking in Latin America and the Caribbean, North Africa, Subsaharan-Africa, southern India and southern Europe). All of those emerged from a common element: the imperial/ colonial expansion that began in the 16 th century and continues to the present day. In short, the Paradigm Other, in its planetary diversity, is connected by a common historical experience: colonialism; and by an essential epistemic principle: the colonial horizon of Modernity (Mignolo, 2000).

Combined with the Paradigm Other, we take and further adapt five propositions about the Anthropocene (Svampa, 2016) as fundamental hypotheses: (1) the Anthropocene is not temporary and does not present itself as a crisis; instead, it marks an extremely critical point of (no) return, because it negates the concept of sustainable development; (2) the Anthropocene calls into question the anthropocentric view that, since modernity was constituted from the separation between human beings and nature, so that it emphasizes we need to overcome the dualist ontology that bases the modern thought; (3) the Anthropocene challenges the control and domination practices of nature that base the view of Modern science, which leads us to search for other ontologies (in the context of the other paradigm of Mignolo (2000) to base new environmental ethics that assure us a sustainable order for the lives of different human beings in 
the world); (4) the Anthropocene is a monolithic concept that shall be placed against the backdrop of socio-political issues. It can be named, and so defined, depending on the power relations at focus as Capitalocene (Moore, 2016; Ulloa, 2017), but we can also speak of the Plantationocene, the Anglocene, among other propositions. As we stress the issue of development, another alternative name comes to the scene, which is the Developmentocene; (5) the Anthropocene shows the geography of consumption and the geography of extractivism, so that responsibility belongs to rich countries as well as to developing countries.

The need to engage with LA thinking should not sound like a reaction against the scientific efforts of researchers located in the Global North, who have contributed to give visibility to the destruction of the planet by human beings, as well as problematizing the causes, responsibilities, and consequences of such destructive action. Attending to Ergene, Callas and Smircich (2018), we are searching for more vocabulary and new terms to keep the conversation about the Anthropocene going, and more to think about, mindful that the occasion of the Anthropocene has opened the door for other discourses and practices to appear. We are also seeking to understand the impact of global events and facts - such as the organizations, the development, the colonization, and the Anthropocene itself - from local perspectives. Such arguing contrasts to the proposing of global solutions to the environmental crises, via worldwide agendas like the UN '2030 Agenda for Sustainable Development', that states to some extent in favor of alternatives that are sustainable development-alike, such as Bio, Green and Circular Economy (Gregorio, Pié, \&Terceño, 2018).

The will to change and move away from conventional development points to a radical perspective, focused on the concept of Buen Vivir. It refers to alternatives to development emerging from indigenous traditions, and explores possibilities beyond the modern eurocentric tradition (Gudynas, 2011). Buen Vivir creates a normative mandate, with explicit appeals to social and ecological justice, from whence it is possible to imagine a future that is preferable to others, which are equally possible (Gudynas, 2013a). Within OS, the implications the concept of Buen Vivir may integrate efforts toward criticizing the past and reimagining the future, to devise alternative paths to the environmental crisis (DeCock, Nyberg, \& Wright, 2019; Ergene, Calás, \& Smircich, 2018), from a LA post-colonial perspective.
At present, OS can channel practical changes towards economic and organizational models to deal with the environmental crises that culminate in the Anthropocene, and overcome current destructive ways of production and consumption that infuses the contemporary lifestyles and ways of being that fit within the developmental dynamics.

Now in the face of the Anthropocene, the normal science perspective organization-nature relationship does not seem to have the power to solve the environmental crisis and elaborate new paths for the economy. Such a concept is at the center of a more significant change in scientific enterprises and knowledge production and may open the possibilities of new paradigm shifts in Organizational Theory. With that in mind, we corroborate that the transition to alternatives to development within the concept of Buen Vivir relies on "new answers to post-development questions while reinforcing powerful cultural innovations and capabilities rooted in the indigenous knowledge and traditions, to face current development strategies" (Gudynas, 2011, p. 445).

\section{CONCLUSIONS}

Whether the Anthropocene is consensual or not, its causes and consequences might be opportunities to question the unified notions of humanity and homogeneous human acting upon nature within the different fields of science, and from diverse standpoints. We aimed to contribute to such a topic with a conceptual paper that we recognize to be just introductory, as understanding the dynamics of (under)development of global North and South and the trajectories of natural depletion under the Great Acceleration is treacherous work. We proposed the thesis that the Anthropocene is coetaneous to the development of the so-considered underdeveloped regions. The Great Acceleration landmark dates the same as the coinage of the (under) development concept, following the post-II World War, and the trajectories of both are intertwined from the beginning. In that manner, we strength and advance the Great Acceleration thesis, adding the issue of development to the scope of arguments that highlight that "only beyond the mid-20th century is there clear evidence for fundamental shifts in the state and functioning of the Earth System that are beyond the range of variability of the Holocene and driven by human activities" (Steffen et al., 2015, p. 81). 
Going a step further, we also dialogued with the various alternative naming for the Anthropocene, aspiring to seize the ongoing global changes from the perspective of colonial-imperial relations forged under the leap forward practice of the idea of development. The proposition of the name Developmentocene comes from the thesis that development and Anthropocene are coetaneous, the intertwinement of both resulting in the very definition of the new epoch. As more as Developmentocene is an alternative naming among others, it brings the issue of development and the power relations attached to the center of the debate on the Anthropocene. It also has the advantages of adding up to the increasingly accepted Great Acceleration thesis and bringing the Earth-System investigation closer to historical and political observable facts. Such advantages could not be said about the Capitalocene, for instance, as much widespread as it is in social sciences' discussions about the Anthropocene. Development as both concept and policies has a precise inauguration date, and it is not a coincidence at all that such a date corresponds to that shown in the graphics of the Great Acceleration of production and consumption. Developmentocene says about the exploitation of the Global South to the benefit of the consumerist lifestyles of the global North.

We suggest to explore further how the second pattern shown on the Great Acceleration graphics which expresses the whiling increase in population, production, consumption and planetary threshold's pressure from 1970 to 2010 , in comparison to the period between 1950 and 2000 - may correspond to the neo-developmental policies adopted in AL by center-left wing governments in the period between 2000 and 2015. The analysis should be extended to the development agenda currently espoused by the right-wing governments currently on power in many LA countries.
We also suggest comparisons of global North and South lifestyles, to understand how the idea of development influences the ways of living in underdeveloped countries, particularly in the BRICS, that have experienced rapid growth in the last decades. Such countries are now home to the so-called global middle-class, which tends to reproduce the consuming patters of the traditional middle-classes of the OECD.

Concerning the naming, we recommend advancing the reflections on alternative framings for the Anthropocene, from the points of contact and divergence of the Developmentocene regarding the other propositions we have mentioned in this paper, and also the ones we could not address here. It is also necessary to advance on the theoretical basis of Developmentocene, by deepening the studies on the development and the consequences of development policies over nature. For that, we may need not only theoretical formulations but empirical studies that can link decolonial perspectives to environmental issues, in the framing of the Anthropocene studies.

Every field may face opportunities and contradictions approaching the Anthropocene. The concept is at the reach of the OS, which can elaborate a purpose for the science of organizations that can be associated with human ways of living with the natural environment. Although the consequences of the Anthropocene are more severe than OS can (or has been proposed to) solve, the participants of this field from all parts of the world shall play a role in the arena of currently structured debates to give authentic referrals to the question. Bounded to this field is to elaborate the transition from theory to practice of conducting business in areas exposed to climate change or deeply affected by the loss of biodiversity, for example. OS offers the possibility of understanding that new types of organizations and what alternative forms of management are needed to meet the challenge of transforming production and consumption to conserve and restore nature. 


\section{REFERENCES}

Baviskar, A., McFarlane, C., Mawdsley, E., \& Jazeel, T. (2015, September). Chair's plenary: Anthropocene or anglocene? Debating cause and consequence in the great climacteric. Discussion panel in Conference of the Royal Geographic Society, Institute of British Geographers meetings, Exeter, England, 3.

Biello, D. (2015, March 11). Mass deaths in americas start new CO2 epoch. Scientific American. Retrieved from https://www.scientificamerican. com/article/mass-deaths-in-americas-start-new-co2-epoch/

Böhm, S., \& Misoczky, M. C. (2010). Mercados de carbono: Imagens do norte e do sul. In M. C. Misoczky, R. K. Flores, \& J. Moraes (Orgs.), Organização e Práxis Libertadora (pp. 131-152). Porto Alegre: Dacasa Editora.

Castree, N. (2017). Unfree radicals: Geoscientists, the anthropocene, and left politics. Antipode, 49(S1), 52-74. https://doi.org/10.1111/anti.12187

Certini, G., \& Scalenghe, R. (2011). Anthropogenic soils are the golden spikes for the anthropocene. The Holocene, 21(8), 1269-1274. https://doi. org/10.1177/0959683611408454

Chagas, P. B., Carvalho, C. A. P., \& Marquesan, F. F. S. (2015). Desenvolvimento e dependência no Brasil nas contradições do programa de aceleração do crescimento. Organizações e Sociedade, 22(73), 269-290. https:// doi.org/10.1590/1984-9230735

Crutzen, J. P., \& Stoermer, E. F. (2000). The anthropocene. IGBP Global Change Newsletter, (41), 17-18. Retrieved from http://www.igbp. net/download/18.31 6f18321323470177580001401/137638308845 2/NL41.pdf

DeCock, C, Nyberg, D., \& Wright, C. (2019). Disrupting climate change futures: Conceptual tools for lost histories. Organization. 1-15. https://doi. org/10.1177/1350508419883377

Dull, R. A., Nevle, R. J., Woods, W. I., Bird, D. K., Avnery, S., \& Denevan, W. M. (2010). The columbian encounter and the little ice age: Abrupt land use change, fire, and greenhouse forcing. Annals of the Association of American Geographers, 100(4), 755-771. https://doi.org/10.1080/ 00045608.2010.502432

Ellis, M. A., \& Trachtenberg, Z. (2013). Which anthropocene is it to be? Beyond geology to a moral and public discourse. Earth's Future, 2(2), 122125. http://dx.doi.org/10.1002/2013EF000191

Ergene, S., Calás, M. B., \& Smircich, L. (2018). Ecologies of sustainable concerns: Organization theorizing for the anthropocene. Gender, Work \& Organization, 25(3), 222-245. https://doi.org/10.1111/ gwao. 12189

Escobar, A. (1997). The making and unmaking of the third world through development. In M. Rahnema, \& V. Bawtree (Eds.), The PostDevelopment Reader (pp. 85-93). London: Zed Books.

Esteva, G. (2010). Development. In W. Sachs (Ed.), The development dictionary: A guide to knowledge as power (pp. 1-23). London: Zed Books.

Galeano, E. (2010). As veias abertas da América Latina. Porto Alegre: L\&PM.

García-Acosta, V. A. (2017). Presentación: La incursión del antropoceno en el sur del planeta. Desacatos, (54), 8-15. Retrieved from http://www. scielo.org.mx/scielo.php?script=sci_arttext\&pid=S1607-050X20170 00200008\&lng=es\&tlng=es.

Gregorio, V. F., Pié, L., \& Terceño, A. (2018). A systematic literature review of bio, green and circular economy trends in publications in the field of economics and business management. Sustainability, 10(11), 4232. https://doi.org/10.3390/su10114232
González-Ruibal, A. (2018). Beyond the anthropocene: Defining the age of destruction. Norwegian Archaeological Review, 51(1-2), 10-21. https://doi.org/10.1080/00293652.2018.1544169

Gudynas, E. (2011). Buen vivir: Today`s tomorrow. Development. 54(4), 441447. https://doi.org/10.1057/dev.2011.86

Gudynas, E. (2013a) Extracciones, extractivismos y extrahecciones: Un marco conceptual sobre la apropriacion de recursos naturales. El Observatorio del Desarrollo, (18) 1-18. Retrieved from http://ambiental.net/wp-content/uploads/2015/12/ GudynasApropiacionExtractivismoExtraheccionesOdeD2013.pdf

Gudynas, E. (2013b). Transitions to post-extractivism: Directions, options, areas of action. In M. Lang, D. Mokrani (Eds.), Beyond development: Alternative visions from Latin America (pp. 165-188). Amsterdam: Transnational Institute, Rosa Luxemburg Foundation.

Hamilton, C. (2015). Getting the anthropocene so wrong. The Anthropocene Review, 2(2), 102-107. https://doi.org/10.1177/2053019615584974

Haraway, D. J. (2016). Staying with the trouble: Makin kin in the chtulucene. Durham and London: Duke University Press.

Kallis, G., Kerschner, C., \& Martinez-Alier, J. (2012). The economics of degrowth. Ecological economics, 84(c), 172-180. https://doi. org/10.1016/j.ecolecon.2012.08.017

Kirsch, S. (2005). Proving grounds: Project plowshare and the unrealized dream of nuclear earthmoving. New Brunswick: Rutgers University Press.

Korhonen, J., Honkasalo, A., \& Seppälä, J. (2018). Circular economy: The concept and its limitations. Ecological Economics, 143(C), 37-46. https://doi.org/10.1016/j.ecolecon.2017.06.041

Lane, R. (2019). The american anthropocene: Economic scarcity and growth during the great acceleration. Geoforum, 99, 11-21. https://doi org/10.1016/j.geoforum.2019.01.003

Lepori, M. (2015). There is no anthropocene: Climate change, species-talk, and political economy. Telos, 2015(172), 103-124. https://doi org/10.3817/0915172103

Lewis, S. L. \& Maslin, M. A. (2015). Defining the anthropocene. Nature, (519), 171-180. https://doi.org/10.1038/nature14258

Lorimer, J. (2017). The Anthropo-scene: A guide to the perplexed. Social Studies of Science, 47(1), 117-142. https://doi.org/10.1177/0306312716671039

Lövbrand, E., Beck, S., Chilvers, J., Forsyth, T., Hedrén, J., Hulme, M., Lidskog, R., \& Vasileiadou, E. (2015). Who speaks for the future of earth? How critical social science can extend the conversation on the anthropocene. Global Environmental Change, 32, 211-218. https:// doi.org/10.1016/j.gloenvcha.2015.03.012

Mignolo, W. D. (2000). Historias locales/diseños globales. Madrid: Ediciones Akal.

Malm, A., \& Hornborg, A. (2014) The geology of mankind? A critique of the anthropocene narrative. The Anthropocene Review. 1(1), 62-69. https://doi.org/10.1177/2053019613516291

Moore, J. W. (2016). Anthropocene or capitalocene? Nature, history, and the crisis of capitalism. Oakland: PM Press.

Moore, J. W. (2017) The Capitalocene, Part I: On the nature and origins of our ecological crisis. The Journal of Peasant Studies, 44(3), 594-630 https://doi.org/10.1080/03066150.2016.1235036 
Morrison, K. D. (2018). Empires as ecosystem engineers: Toward a nonbinary political ecology. Journal of Anthropological Archaeology, 52, 196203. https://doi.org/10.1016/j.jaa.2018.09.002

Rist, G. (2019). The history of development: From western origins to global faith. London: Zed Books.

Sachs, I. (1981) Ecodesarrollo: Concepto, aplicación, benefícios y riesgos. Agricultura y Sociedad, (18), 9-32. Retrieved from https://dialnet. unirioja.es/servlet/articulo?codigo $=82465$

Santos, B. S. (2010). Para além do pensamento abissal: Das linhas globais a uma ecologia de saberes. Novos estudos CEBRAP, (79), 71-94.

Schneider, F., Kallis, G., \& Martinez-Alier, J. (2010). Crisis or opportunity? Economic degrowth for social equity and ecological sustainability. Introduction to this special issue. Journal of Cleaner Production, 18(6), 511-518. https://doi.org/10.1016/j.jclepro.2010.01.014

Steffen, W., Crutzen, P. J., \& McNeill, J. R. (2007). The anthropocene: Are humans now overwhelming the great forces of nature? Ambio, 36(8), 614-621. https://doi.org/10.1579/0044-7447(2007)36[614:taahno]2.0.co;2

Steffen, W., Grinevald, J., Crutzen, P., \& McNeill, J. (2011). The anthropocene: Conceptual and historical perspectives. Philosophical Transactions of the Royal Society A: Mathematical, Physical and Engineering Sciences, 369(1938), 842-867. https://doi.org/10.1098/rsta.2010.0327

\section{Authors}

\section{Marina Dantas de Figueiredo}

Av. Washington Soares, $\mathrm{n}^{\circ}$ 1321, Edson Queiroz, 60811-025, Fortaleza, CE, Brazil.

E-mail address: marina.dantas@gmail.com

๑ https://orcid.org/ 0000-0003-3273-8176

\section{Fábio Freitas Schilling Marquesan*}

Av. Washington Soares, $n^{\circ}$ 1321, Edson Queiroz, 60811-025, Fortaleza, CE, Brazil.

E-mail address: marquesan@unifor.br

() https://orcid.org/0000-0002-2456-4914

\section{José Miguel Imas}

Kingston University, River House, 53-57 High Street, Kingston upon Thames, Surrey KT1 1LQ, Thames, United Kingdom.

E-mail address: j.imas@kingston.ac.uk

○ https://orcid.org/0000-0003-2947-8086

* Corresponding Author

\section{Funding}

The research that supports the data in this article was carried out with financial support from the Research, Development and Innovation Directorate of the University of Fortaleza (DPDI/Unifor), Brazil.

\section{Conflict of Interest}

The authors have stated that there is no conflict of interest.

\section{Copyrights}

RAC owns the copyright to this content.
Steffen, W., Broadgate, W., Deutsch, L., Gaffney, O., \& Ludwig, C. (2015). The trajectory of the anthropocene: The great acceleration. The Anthropocene Review, 2(1), 81-98. https://doi.org/10.1177/2053019614564785

Svampa, M. (2016). El antropoceno, un concepto que sintetiza la crisis civilizatoria. Transcripción de la Radio comunitaria Kalewche.. Retrieved from https://www.kalewchefm.org/columnistas/maristella-svampa/3097-elantropoceno-un-concepto-que-sintetiza-la-crisis-civilizatoria

Tsing, A. (2015, February) Feral biologies. Proceedings of the Inaugural Conference on Anthropological Visions of Sustainable Futures, London, UK, 1.

Ulloa, A. (2017). Dinámicas ambientales y extractivas en el siglo XXI: ¿Es la época del antropoceno o del capitaloceno en latinoamérica? Desacatos, 54(2), 58-73. https://doi.org/10.29340/54.1740

Waters, C. N., Zalasiewicz, J., Summerhayes, C., Barnosky, A. D., Poirier, C., Galuszka, A., Cearreta, A., Edgeworth, M., Ellis, E. C., Jeandel, C., Leinfelder, R., McNeill, J. R., Richter, D. B., Steffen, W., Syvitski, J., Vidas, D., Wagreich, M., Williams, M., Zhisheng, A., Grinevald, J., Odada, E., Oreskes, N., \& Wolfe, A. P. (2016). The anthropocene is functionally and stratigraphically distinct from the holocene. Science, 351(6269), aad2622. https://doi.org/10.1126/science.aad2622

\section{Authors' Contributions}

$\mathbf{1}^{\text {st }}$ author: Contributed equally with the conceptualization, acquisition of materials and interpretation of data, writing of the text, critical review and approval of the final version.

$2^{\text {nd }}$ author: Contributed equally with the conceptualization, acquisition of materials and interpretation of data, writing of the text, critical review and approval of the final version. $3^{\text {rd }}$ author: Contributed equally with the conceptualization, acquisition of materials and interpretation of data, writing of the text, critical review and approval of the final version.

\section{Plagiarism Check}

The RAC maintains the practice of submitting all documents approved for publication to the plagiarism check, using specific tools, e.g.: iThenticate.

\section{Peer Review Method}

This content was evaluated using the double-blind peer review process. The disclosure of the reviewers' information on the first page is made only after concluding the evaluation process, and with the voluntary consent of the respective reviewers. 